\title{
Optimalisasi Biaya Total Perencanaan dan Pengendalian Persediaan Menggunakan Program Dinamik (Studi Kasus : Nabila Bakery SPMA Kalasey Manado)
}

\author{
${ }^{1}$ Putri Delfianda, ${ }^{2}$ Hanny Komalig, ${ }^{3}$ Tohap Manurung \\ ${ }^{1}$ Program Studi Matematika, FMIPA, UNSRAT, putridelfianda@gmail.com \\ ${ }^{2}$ Program Studi Matematika, FMIPA, UNSRAT, hanoy07@ yahoo.com \\ ${ }^{3}$ Program Studi Matematika, FMIPA, UNSRAT, kris_ton79@yahoo.com
}

\begin{abstract}
Abstrak
Program dinamik adalah Salah satu teknik matematika yang digunakan untuk mengoptimalkan proses pengambilan keputusan secara bertahap ganda dengan membagi satu persoalan atas beberapa bagian persoalan (tahap), kemudian memecahkan tiap tahap sampai seluruh persoalan telah terpecahkan. Tujuan dari penelitian ini untuk mengoptimalan total biaya produksi sesuai dengan hasil penjadwalan roti tawar di nabila bakery menggunakan program dinamik dengan pendekatan rekursif maju dan rekursif mundur. Dengan berdasarkan hasil ramalan menggunakan regresi linear diperiode mendatang mei 2014 sampai april 2015. Diketahui bahwa biaya total optimal (minimum) yang diperoleh untuk roti tawar selama satu tahun adalah Rp. 1.041.411.000. Dari biaya minimum dengan program dinamik diperoleh profit lebih optimal dibanding sebelum menggunakan program dinamik.
\end{abstract}

Kata kunci: Biaya Minimum, Program Dinamik, Regresi Linier.

\section{Optimization of Total Cost of Planning and Inventory Control Using Dynamic Programming (Case Study: Nabila Bakery SPMA Kalasey Manado)}

\begin{abstract}
Dynamic programming is a mathematical techniques used to optimize the decision process gradually double by dividing the issue on several parts of the question (phase), and then solve each stage until all problems have been solved. The purpose of this research is to minimize the total cost of production in accordance with the scheduling results in nabila bakery white bread using Dynamic Programming with approach Foreward recursive and Backward recursive. Basis on the results of forecast using linear regression upcoming period May 2014 to April 2015. From of discussion it is known that the total cost of the optimal (minimum) obtained for white bread for a year is Rp. 1.041.411.000. From of the cost of the dynamic program can be seen profits more than before using optimal dynamic program.
\end{abstract}

Key Words: Minimum Cost, Dynamic Programming, Linear Regression.

\section{Pendahuluan}

Meningkatnya persaingan industri yang semakin maju mengakibatkan persaingan bisnis semakin ketat, sehingga setiap perusahaan akan bersaing dalam memberikan pelayanan yang memuaskan bagi pelanggannya. Sangat penting bagi perusahaan untuk merencanakan operasional produksi dengan tepat supaya dapat meminimalisir biaya-biaya yang diperlukan untuk kegiatan produksi. Perusahaan-perusahaan bergerak dibidang yang sama akan berusaha untuk meningkatkan kualitas produk dan pelayanannya supaya dapat bertahan dan bersaing di dalam industri. Dan juga bisa jadi merupakan ancaman bagi perusahaan pendatang baru maupun pemain lama karena akan berdampak pada profit yang dihasilkan. Oleh karena itu, agar perusahaan tidak mengalami penurunan profit dan dapat bertahan pada bisnis yang sedang berjalan diperlukan cara yang tepat untuk mengalahkan pesaingnya salah satunya dengan cara melakukan peramalan penjualan dari produk yang dihasilkan.

Perusahaan nabila bakery merupakan salah satu usaha dagang yang bergerak dalam produksi roti tawar. Usaha yang sudah berdiri pada tahun 2011 ini sering mengalami masalah dalam memperkirakan jumlah produk yang harus di produksi, menyebabkan sering terjadinya 
kelebihan produksi dan perolehan keuntungan menjadi tidak optimal. Dalam perusahaan, pengendalian persediaan mempunyai manfaat yang sangat penting untuk meminimumkan biaya produksi sehingga dapat menghasilkan profit yang optimal. Menurut [1], fungsi pengendalian persediaan saat kondisi dimana seringkali jumlah yang diproduksi lebih besar daripada yang dibutuhkan. Karena sebagian barang atau bahan yang belum digunakan disimpan sebagai persediaan, namun persediaan juga menyebabkan penekanan ongkos dan perputaran modal secara keseluruhan terhambat. Salah satu pendekatan solusi yang dapat dipakai dalam memecahkan masalah pengendalian persediaan dan meminimumkan biaya total produksi sesuai hasil penjadwalan adalah dengan menggunakan metode program dinamik. Dan peramalan jumlah permintaan produk roti tawar digunakan metode regresi linear. Selanjutnya hasil dari peramalan tersebut digunakan untuk merencanakan produksi dan pengendalian persediaan untuk meminimumkan biaya total produksi dengan program dinamik.

Program dinamik adalah Salah satu teknik matematika yang digunakan untuk mengoptimalkan proses pengambilan keputusan secara bertahap ganda [1]. Inti dari tehnik ini ialah membagi satu persoalan atas beberapa bagian persoalan (tahap), kemudian memecahkan tiap tahap sampai seluruh persoalan telah terpecahkan. Prosedur pemecahan persoalan dalam program dinamik dilakukan secara rekursif. Artinya, bahwa setiap kali diambil keputusan, diperhatikan keadaan yang dihasilkan oleh keputusan sebelumnya. Pada penelitian sebelumnya, [2] telah membahas penggunaan program dinamik pada pengendalian persediaan. Tujuan dari penelitian ini adalah untuk mengetahui optimalisasi total biaya pengendalian persediaan dengan menggunakan program dinamik secara rekursif maju dan mundur.

\section{Analisis Regresi Linier}

Metode regresi linier sering sekali dipakai untuk memecahkan masalah-masalah dalam penaksiran tentunya hal ini berlaku juga dalam peramalan sehingga metode regresi linier menjadi suatu metode yang mempunyai taksiran terbaik diantara metode-metode yang lain. Metode regresi linier dipergunakan sebagai metode peramalan apabila pola historis dari data actual permintaan menunjukkan adanya suatu kecenderungan menaik dari waktu ke waktu. Persamaan regresi linear di tuliskan sebgai berikut [3]:

$$
\hat{Y}=a+b X
$$

Dengan taksiran a dan $\mathrm{b}$ masing-masing menyatakan perpotongan dengan sumbu $\mathrm{y}$ dan kenaikannya. Slope dan intersept dari persamaan regresi linier dihitung dengan menggunakan persamaan berikut [3]:

$$
b=\frac{n \sum X_{i} Y_{i}-\sum X_{i} \sum Y_{i}}{n \sum X_{i}^{2}-\left(\sum X_{i}\right)^{2}} \quad a=\sum \frac{Y_{i}}{n}-b \sum \frac{X_{i}}{n}
$$

\subsection{Koefisien korelasi}

Koefisien korelasi $(r)$ dipakai untuk mengetahui derajat hubungan antar variabel, koefisien korelasi dapat ditentukan dengan mengambil akar dari koefisien determinasi $\left(R^{2}\right)$. Nilai-nilai $r$ dapat memberi arti sebagai berikut [4]:

Tabel 1. Interpretasi dari Nilai $r$

\begin{tabular}{|c|c|}
\hline$r$ & Interpretasi \\
\hline 0 & Tidak berkorelasi \\
$0,01-0,20$ & Sangat rendah \\
$0,21-0,40$ & Rendah \\
$0,41-0,60$ & Agak rendah \\
$0,61-0,80$ & Cukup \\
$0,81-0,99$ & Erat \\
1 & Sangat erat \\
\hline
\end{tabular}




\subsection{Uji Akurasi Peramalan}

Salah satu ukuran statistik yang digunakan untuk mengetahui ketepatan model dalam peramalan adalah MAD (Mean Absolute Deviation) semakin kecil. MAD merupakan nilai total absolut dari forecast error dibagi dengan data. Atau yang lebih mudah adalah nilai kumulatif absolut error dibagi dengan periode. Jika diformulasikan maka formula untuk menghitung MAD adalah sebagai berikut [5]:

$$
M A D=\sum_{i=1}^{n} \frac{\left|e_{i}\right|}{n}=\sum_{i=1}^{n} \frac{\left|Y_{i}-\hat{Y}_{i}\right|}{n}
$$

\section{Pengendalian Persediaan}

Masalah pengendalian persediaan merupakan salah satu masalah penting yang dihadapi oleh perusahaan. Kekurangan bahan baku akan mengakibatkan adanya hambatan-hambatan pada proses produksi. Kekurangan persediaan barang jadi di pasaran akan menimbulkan kekecewaan pada pelanggan dan akan mengakibatkan perusahaan kehilangan mereka, sedangkan kelebihan persediaan akan menimbulkan biaya ekstra (biaya penyimpanan dan lain-lain), di samping resiko kerusakan karena penyimpanan barang yang terlalu lama. Sehingga dapat dikatakan bahwa pengendalian persediaan yang efektif sangat diperlukan oleh suatu perusahaan [1].

\section{Program Dinamik}

Program dinamik adalah Salah satu teknik matematika yang digunakan untuk mengoptimalkan proses pengambilan keputusan secara bertahap ganda [1]. Suatu masalah pengambilan keputusan yang multistage dipisahpisahkan menjadi suatu sub masalah yang berurutan dan saling berhubungan. Program dinamik terbagi menjadi dua yaitu secara deterministik dan probabilistik. Pada masalah program dinamik deterministik, state yang berada pada tahapan berikutnya ditentukan seluruhnya berdasarkan state dan kebijakan keputusan pada tahapan sebelumnya. Sedangkan pemrograman dinamik probabilistik, terdapat suatu probabilitas keadaan mendatang yang distribusi peluang ini tetap ditentukan oleh keadaan dan keputusan kebijakan pada keadaan sebelumnya [6].

Sebuah objek disebut berulang (rekursif, recursive) jika setiap objek mengandung dirinya sendiri atau didefinisikan dengan dirinya sendiri. Dalam matematika, defenisi rekursif sebuah fungsi adalah defenisi fungsi yang menggunakan fungsi tersebut. Ada dua macam prosedur rekursif yaitu forward recursive equation (perhitungan dari depan ke belakang) dan backward recursive equation (perhitungan dari belakang ke depan).

\subsection{Rekursif foreward and Rekursif backward}

Foreward recursive equation (perhitungan dari depan ke belakang) [7].

$$
\left.f_{j}\left(x_{j}\right)=\text { opt }\left\{R_{j}\left(k_{j}\right)+f_{j+1} \mid x_{j}-c_{j}\left(k_{j}\right)\right\}\right\}, j=2,3
$$

Perhitungan yang dilakukan dengan menggunakan urutan metode :

$$
f_{1} \rightarrow f_{2} \rightarrow f_{3}
$$

Backward recursive equation (perhitungan dari belakang ke depan) [7].

$$
\left.f_{j}\left(y_{j}\right)=\operatorname{opt}\left\{R_{j}\left(k_{j}\right)+f_{j+1} \mid y_{j}-c_{j}\left(k_{j}\right)\right]\right\}, j=2,3
$$

Perhitungan tahap urutan dengan demikian adalah

\subsection{Formulasi dengan Program Dinamik}

$$
f_{3} \rightarrow f_{2} \rightarrow f_{1}
$$

Urutan perencanaan produksi dengan program dinamik ditunjukkan pada tahapan berikut :

1. Dekomposisi, permasalahan rencana produksi dipecah menjadi beberapa sub masalah dalam penelitian ini dinyatakan dengan tahap 1 sampai tahap 12 .

2. Menentukan variabel masukan atau state pada tiap tahapan, dalam hal ini adalah hasil peramalan, kapasitas tersedia, biaya variabel produk, dan biaya simpan. 
3. Menentukan variabel keputusan, dalam penelitian ini adalah menentukan jumlah produksi berdasarkan persediaan.

4. Menetapkan fungsi tujuan :

5. Dengan batasan

$$
\operatorname{Min} C=\sum_{n=1}^{12}\left(A . X_{n}+B . I_{n}\right)
$$

Jumlah produksi yang dilakukan tidak melebihi kapasitas produksi yang tersedia. Formulasi matematisnya, yaitu : $I_{n}+S_{n}-G \leq X_{n} \leq I_{n}+S_{n}$

6. Menetapkan persamaan rekursif

Penyelesaian program dinamik dilakukan dengan perhitungan rekursif yang berulang setiap tahap. Keputusan optimum pada suatu tahap adalah hasil optimum pada tahap tersebut ditambah hasil optimum tahap sebelumnya.

$$
f_{n}\left(I_{n}\right)=\min \left\{\left(A x_{n}+Y\left(I_{n}\right)+f_{n-1}\left(I_{n-1}\right)\right)\right\}, n=1,2,3, \ldots .12
$$

Persamaan rekursif di atas dapat ditulis, sebagai berikut :

Rekursif maju

$$
f_{n}\left(I_{n}\right)=\min \left\{\left(A x_{n}+B\left(I_{n}\right)\right)+f_{n-1}\left(I_{n}+S_{n}-X_{n}\right)\right\}
$$

Rekursif mundur $\quad: f_{n}\left(I_{n}\right)=\min \left\{\left(A x_{n}+B\left(I_{n}\right)\right)+f_{n+1}\left(I_{n}+S_{n}-X_{n}\right)\right\}$

Keterangan :

$f_{n}\left(I_{n}\right)=$ biaya produksi minimum roti pada tahap $n$ dalam banyak persediaan $S$

$A x_{n}=$ biaya produksi $x$ buah roti dalam tahap $n$

$B\left(I_{n}\right)$ = biaya perawatan yang dikenakan terhadap tahap $n$ apabila dalam banyaknya persediaan $I$

Sn $=$ banyaknya Permintaan atau penjualan dalam tahap $n$

\section{Metodologi Penelitian}

Data yang digunakan dalam penelitian ini adalah data sekunder yaitu data jumlah produksi roti tawar dari Mei 2013 sampai dengan April 2014. Peramalan untuk permintaan jumlah produksi roti tawar yang harus diproduksi periode Mei 2014 sampai dengan April 2015 dilakukan dengan metode regresi linear dengan bantuan software analisis statistika. Hasil peramalan tersebut digunakan untuk perencanaan produksi dan pengendalian persediaan untuk meminimumkan biaya. total minimum produksi.

\section{Hasil dan Pembahasan}

\subsection{Analisis Data Permintaan Roti Tawar}

Data yang digunakan adalah jumlah permintaan roti tawar periode Mei 2013 sampai dengan April 2014 sehingga jumlah data yang digunakan ada 12. Berikut informasi secara deskriptif yang diperoleh berdasarkan software analisis statistika seperti pada gambar 1 .

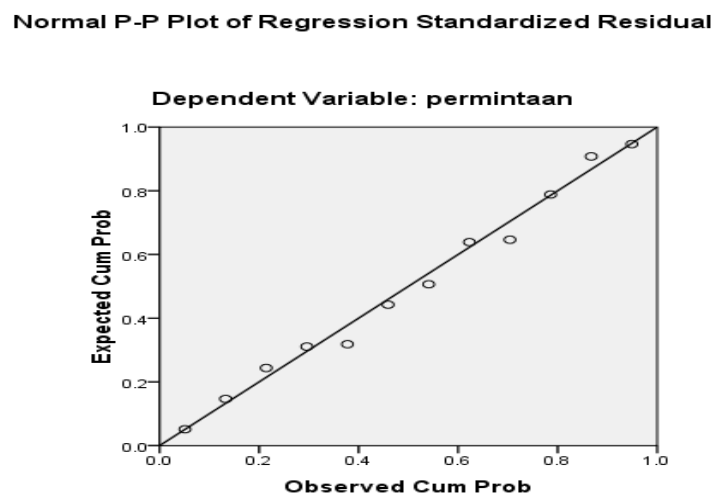

Gambar 1. Normal P-P Plot variabel permintaan 
Uji normalitas dipergunakan untuk menentukan apakah data berdistribusi secara normal atau tidak. Uji normalitas yang di pergunakan adalah dengan melihat gambar Normal P-P Plot dimana asumsi normalitas terpenuhi jika data menyebar disekitar garis diagonal dan mengikuti arah garis diagonal yang di tentukan berdasarkan data (residual) [8]. Dapat dilihat pada gambar 1. Setelah itu melakukan uji lineritas melihat kelinearan data.

Uji linearitas yang dipakai adalah uji lagrange multiplier untuk melihat model linear atau tidak. Uji lagrange multiplier estimasi dengan uji ini bertujuan untuk mendapatkan nilai $c^{2}$ hitung atau $\left(n \times R^{2}\right)$. Hasil pada tabel 2. menunjukkan nilai $R^{2}$ sebesar 0.956 dengan jumlah $\mathrm{n}$ observasi 12 , maka besarnya nilai $c^{2}$ hitung $=12 \times 0.956=11.472$. Nilai ini dibandingkan dengan $c^{2}$ tabel dengan $d f=10$ dan tingkat signifikansi 0.05 didapat nilai $c^{2}$ tabel 18.307. Oleh karena nilai $c^{2}$ hitung lebih kecil dari $c^{2}$ tabel maka dapat disimpulkan bahwa model linear. Tampilan output analisis statistika pada tabel 2. menunjukkan nilai adjusted $R^{2}$ cukup tinggi $95.3 \%$ yang artinya variabilitas permintaan yang dapat dijelaskan oleh variabel periode sekitar $95.3 \%$ dan sisanya $4.7 \%$ dijelaskan oleh variabel lain diluar model penelitian ini. Jadi dapat disimpulkan model cukup baik.

Tabel 2. Uji linearitas

\begin{tabular}{|c|c|c|c|c|c|}
\hline \multicolumn{6}{|c|}{ Model Summary $^{\mathbf{b}}$} \\
\hline Model & $\mathrm{R}$ & R Square & $\begin{array}{l}\text { Adjusted R } \\
\text { Square }\end{array}$ & $\begin{array}{c}\text { Std. Error of the } \\
\text { Estimate }\end{array}$ & $\begin{array}{l}\text { Durbin- } \\
\text { Watson }\end{array}$ \\
\hline 1 & $.978^{\mathrm{a}}$ & .957 & .953 & 257.448 & .996 \\
\hline
\end{tabular}

\subsection{Analisis Regresi Linear}

Persamaan regresi dalam model ini adalah $\hat{Y}=6318+322(X)$. Dimana $\hat{Y}$ adalah ramalan permintaan dan $X$ adalah periode. Kofisien regresi $X$ sebesar 322 mempunyai arti bahwa setiap penambahan 1 periode maka ada penambahan jumlah permintaan roti sebesar 322 buah. Program analisis statistika dapat diperoleh ramalan untuk 12 periode ke depan dengan taraf kepercayaan 95.3 \%. Interval ramalan dapat dilihat pada Tabel 2: kemudian setelah hasil peramalan dengan analisis regresi linear diselesaikan maka dilanjutkan dengan penyesuaian terhadap prosentase cacat produk.

Tabel 3. Hasil Peramalan Permintaan Periode Mei 2014 - April 2015

\begin{tabular}{|c|c|c|}
\hline No & Periode & $\begin{array}{c}\text { Ramalan Permintaan } \\
\text { ( Buah ) }\end{array}$ \\
\hline 1 & May-14 & 10504 \\
\hline 2 & Jun-14 & 10826 \\
\hline 3 & Jul-14 & 11148 \\
\hline 4 & Aug-14 & 11470 \\
\hline 5 & Sep-14 & 11792 \\
\hline 6 & Oct-14 & 12114 \\
\hline 7 & Nov-14 & 12436 \\
\hline 8 & Dec-14 & 12758 \\
\hline 9 & Jan-15 & 13080 \\
\hline 10 & Feb-15 & 13402 \\
\hline 11 & Mar-15 & 13724 \\
\hline 12 & Apr-15 & 14046 \\
\hline
\end{tabular}


Tabel 4. Hasil penyesuaian terhadap prosentase cacat produk periode Mei 2014 - April 2015

\begin{tabular}{|c|c|c|}
\hline No & Periode & $\begin{array}{c}\text { Jumlah yang harus di produksi } \\
\text { (buah) }\end{array}$ \\
\hline 1 & May-14 & 10610 \\
\hline 2 & Jun-14 & 10935 \\
\hline 3 & Jul-14 & 11260 \\
\hline 4 & Aug-14 & 11576 \\
\hline 5 & Sep-14 & 11911 \\
\hline 6 & Oct-14 & 12236 \\
\hline 7 & Nov-14 & 12561 \\
\hline 8 & Dec-14 & 12886 \\
\hline 9 & Jan-15 & 13212 \\
\hline 10 & Feb-15 & 13537 \\
\hline 11 & Mar-15 & 13862 \\
\hline 12 & Apr-15 & 14187 \\
\hline
\end{tabular}

Kemudian mengukur ketepatan peramalan menggunakan nilai tengah kesalahan absolut (MAD). Dengan menggunakan rumus :

$$
\begin{array}{r}
M A D=\sum_{i=1}^{n} \frac{\left|e_{i}\right|}{n}=\sum_{i=1}^{n} \frac{|Y-\hat{Y}|}{n} \\
M A D=\frac{2313}{12}=192.75
\end{array}
$$

Selanjutnya hasil peramalan digunakan untukmelakukan perencanaan produksi selama 12 periode kedepan dengan menggunakan program dinamik. Perhitungan dengan metode program dinamik menggunakan fungsi rekursif dengan biaya variabel produk per kemasan sebesar Rp 7.000,00 dan biaya simpan produk per kemasan sebesar Rp 500,00 dimana setiap tahap saling berhubungan dan perhitungan dimulai dari tahap 1 sampai dengan tahap 12 dengan ketentuan sebagai berikut:

$f_{n}\left(I_{n}\right)=\min \left\{\left((7000) x_{n}+(500) I_{n}\right)+f_{n-1}\left(I_{n}+S_{n}-X_{n}\right)\right\}$

$0 \leq I_{n} \leq 2000$

$I_{b}+S_{n}-2000 \leq x_{n} \leq I_{n}+S_{n}$

(untuk $n=1,2,3, . .12$ )

\subsection{Penyelesaian dengan Program Dinamik Rekursif Maju}

Penyelesaian dengan rekursif maju yaitu melakukan penyusunan perencanaan produksi dengan biaya minimum menggunakan metode program dinamik untuk jangka waktu perencanaan 1 tahun dengan periode 1 bulan, sehingga ada 12 tahap pelaksanaan yang dimulai pada periode bulan mei 2014-april 2015. Jumlah produksi yang paling optimal akan di peroleh berdasarkan jumlah total biaya produksi minimum yang terdapat pada masing-masing kebijakan produksi yang di susun. Tahap-tahap perhitungan metode program dinamik sebagai berikut :

Tahap 1.

$$
\begin{gathered}
f_{1}\left(I_{1}\right)=\operatorname{Min}\left\{\left(A \cdot X_{1}+B .\left(I_{1}\right)\right\}, I_{1}+S_{1}-I_{0} \leq I_{0}+S_{0}\right. \\
10610 \leq X_{1}
\end{gathered}
$$

Dan jumlah penjualan dalam periode pertama adalah 10610 dengan $0 \leq I 1 \leq 7000$. Sehingga didapat hasil sebagai berikut :

$f 1(0)=7000.10610+500.0=74270000$

$f 1(1000)=7000.11610+500.1000=81770000$

$f 1(2000)=7000.12610+500.2000=89270000$

Dengan biaya perhitungan tersebut berulang sampai tahap ke-12 yaitu April 2015 


\subsection{Penyelesaian dengan Program Dinamik Rekursif Mundur}

Penyelesaian dengan program dinamis untuk masalah yang sama dapat pula dilakukan secara mundur, yaitu mulai dari tahap 12 (April 2015) mundur sampai ke tahap 1 (Mei 2014).

Tahap 12.

$$
f_{12}\left(I_{12}\right)=\operatorname{Min}\left\{\left((7000) \cdot X_{12}+(500) I_{12}\right)\right\}
$$

$f_{12}(0)=7000.12187+500.0=99309000$

$f_{12}(1000)=7000.13187+500.1000=106809000$

$f_{12}(2000)=7000.14187+500.2000=114309000$

Dalam tahap ini biaya produksi minimum terdapat pada $I_{12}=0$ dengan biaya Rp. 99.309.000,-

Tahap 11. $f_{11}\left(I_{11}\right)=\operatorname{Min}\left\{\left(7000 . X_{11}+500 . I_{11}\right)+f_{12}\left(I_{11}+S_{11}-X_{11}\right)\right\}$

Hal serupa seperti di atas dilakukan untuk setiap perhitungan mundur sampai tahap ke-1 yaitu Mei 2014. Hasil penjadwalan produksi untuk 12 periode mendatang dapat dilihat pada tabel 5 .

Tabel 5. Hasil penjadwalan produksi roti periode Mei 2014-April 2015

\begin{tabular}{|c|c|c|r|r|r|}
\hline Periode & $\begin{array}{c}\text { Permintaan } \\
\text { (Buah) }\end{array}$ & $\begin{array}{c}\text { Produksi } \\
\text { (Buah) }\end{array}$ & $\begin{array}{c}\text { Persediaan } \\
\text { (Buah) }\end{array}$ & $\begin{array}{c}\text { Biaya Minimum } \\
\text { Rekursif Maju } \\
(\mathrm{Rp})\end{array}$ & $\begin{array}{c}\text { Biaya Minimum } \\
\text { Rekursif mundur } \\
\text { (Rp) }\end{array}$ \\
\hline Mei 14 & 10610 & 10610 & 0 & 74.270 .000 & 1.041 .411 .000 \\
\hline Jun 14 & 10935 & 10935 & 0 & 150.815 .000 & 967.141 .000 \\
\hline Jul 14 & 11260 & 11260 & 0 & 229.635 .000 & 890.596 .000 \\
\hline Aug 14 & 11576 & 11576 & 0 & 310.667 .000 & 811.776 .000 \\
\hline Sep 14 & 11911 & 11911 & 0 & 394.044 .000 & 730.744 .000 \\
\hline Oct 14 & 12236 & 12236 & 0 & 479.696 .000 & 647.367 .000 \\
\hline Nov 14 & 12561 & 12561 & 0 & 567.623 .000 & 561.715 .000 \\
\hline Dec 14 & 12886 & 12886 & 0 & 657.825 .000 & 473.788 .000 \\
\hline Jan 15 & 13212 & 13212 & 0 & 750.309 .000 & 383.586 .000 \\
\hline Feb 15 & 13537 & 13537 & 0 & 845.068 .000 & 291.102 .000 \\
\hline Mar 15 & 13862 & 13862 & 0 & 942.102 .000 & 196.343 .000 \\
\hline Apr 15 & 14187 & 14187 & 0 & 1.041 .411 .000 & 99.309 .000 \\
\hline
\end{tabular}

Setelah melakukan perhitungan dengan menggunakan program dinamis maka dapat diketahui rencana produksi untuk setiap periode yaitu produksi dengan biaya yang minimum dan akan menghasilkan suatu solusi yang optimal pada keseluruhan tahap penjadwalan.

\section{Kesimpulan}

Dari analisis yang telah dilakukan untuk memperoleh total biaya minimum permintaan dengan menghitung biaya total minimum dengan program dinamik diperoleh biaya total minimum sebesar Rp. 1.041.411.000.-

\section{Daftar Pustaka}

[1] Subagyo, P. dkk. 2000. Dasar-Dasar Operations Research. Edisi-2. PT. BPFE, Yogyakarta.

[2] Nurhayati, F. 2010. Penggunaan Program Dinamik untuk Menentukan Total Biaya Minimum pada Perencanaan Produksi dan Pengendalian Persediaan. Laporan Tugas Akhir. Jurusan Matematika Fakultas Sains dan Teknologi, Universitas Negeri Maulana Malik Ibrahim, Malang.

[3] Hasan, I. 1999. Pokok-Pokok Materi Statistika 2 (Statistik Inferensif). Bumi Aksara, Jakarta. 
[4] Usman, H. dan S.A. Purnomo. 2006. Pengantar Statistika. PT. Bumi Aksara, Jakarta.

[5] Gasperz, V. 2004. Production Planning and Inventory Control. PT Gramedia Pustaka Utama, Jakarta.

[6] Rangkuti, A. 2013. 7 Model Riset Operasi \& Aplikasinya. Brilian Internasional. Surabaya.

[7] Taha, H. A. 1996. Riset Operasi. Edisi 5. Binarupa Aksara, Jakarta.

[8] Ghozali. 2006. Aplikasi Analisis Multivariate dengan Program SPSS. Edisi-4. Badan Penerbit Universitas Diponegoro, Semarang. 